\title{
斜位乳児のハンドリングの指導について
}

\author{
長崎県立整肢療育園* \\ ○川口幸義・松下 明成 \\ 河合 尚志・古田千事
}

\section{Handlings of Infants with Oblique Posture}

\author{
by

\section{Y. Kawaguchi, A. Matsushita, T. Kawai, and S. Furuta}

Nagasaki Prefectural Seishi Ryôikuen

\begin{abstract}
Infants often take an asymmetrical posture and muscle tone, that is, one sided flattening of the skull, postural scoliosis, limitation of abduction of the flexed hip, pelvic obliquity and so on.

In this study, we described the significance of the these oblique posture in infancy and the techniques of their handlings.

In order to prevent the occurrance of deformity of the skull, new-born babies should be put into the side position for the first four months. After that they should be kept in the prone position.

When an oblique posture was noticed in infants, we advised their mothers to do some handlings which were based on the righting and balance reactions: for example, oblique suspension.
\end{abstract}

\section{は じめに}

非対称性姿勢, 筋緊張や運動機能に左右差を有する 児，いわゆる「斜位乳児 (schiefe Säugling)」は保 健所乳児検診や外来診察において，しばしばみかける 徵候である。

筋性斜頸, 分婏麻㾝, 先天性側彎症, 痙性片麻㾝, 股関節脱臼，内反足などの明らかな異常がある児では その治療を行なうのが当然であるが，まだ病的とまで はいっていない斜位乳児（斜頭, 斜頸位, 側弶, 一側 の開排制限，外見上の下肢長差などを有する乳児）に 対しては家庭でのハンドリングの指導を行ないながら の経過観察を余儀なくされることが多い。乙れら斜位 障害を有する児に対して我々が母親に指導している八 ンドリングを紹介するとともに，若干の考察を加え た.

* 諫早市永昌東町195番地

\section{1. 斜頭及び見かけ上の下肢長差について}

後頭部の扁平化，すなわち斜頭は正常乳児でもよく みられる変形である. 新生児頭部血腫, 産瘤などによ る変形や先天性頭部奇形を除く之, 新生児では斜頭は なく, 生後 $2 \sim 3$ 週より出現してくる.

1 力月から 7 カ月までの正常乳児について斜頭の有 無を調べたとてろ，頭部変形のない者 $25 \%$ ，右後頭 部が扁平になった右斜頭は $45 \%$, 後 頭部全体が扁平 な扁平頭蓋 $5 \%$, 左側が扁平な左斜頭は $25 \%$ の割 合 であった. 即ち右斜頭のある児が約半数, 次いで変形 のない児と左斜頭がそれぞれ 4 人に 1 人の割合であっ た.

正常乳児の頭部变形亡外見上の下肢長差との関係を みると，頭部変形のない児では殆んど下肢長差もみら れず，右斜頭では左下肢に見かけ上の短縮があり，逆 に左斜頭では右下肢に見かけ上の短縮がみられる児が 多い（表 1). この下肢長差は骨盤の傾斜・回旋によ 
表 1 斜頭と見かけ上の下肢長差

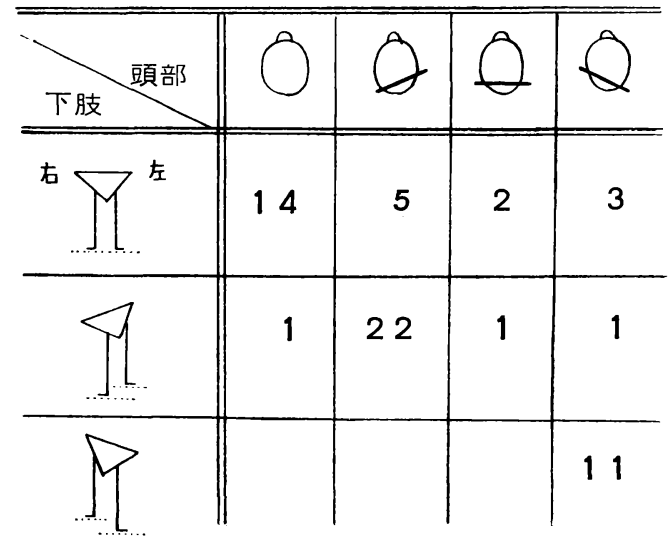

るあのであり，後頭側の骨盤が挙上することによって 生ずる.

\section{2. 疾患の左右差について}

側彎症の中で最も多い特発性側彎症の胸椎部カーブ は右凸が多いのは周知のとおりであり，整形外科的疾 患にはいくつかの左右差が述べられている，長崎県立 整肢療育園の外来受診児 1016 人中，ペルテス病，筋 性斜頸，内反足，偏側肥大症の左右別頻度を調べてみ たが，特に左右差は認められなかった，先天股脱は左 側に多いという報告ああるが，同じ調査で，開排制限 は右 10 人, 両 27 人, 左 18 人, 臼蓋形成不全は右 8 人, 両 10 人, 左 15 人, 亜脱臼は右 3 人, 両 0 人, 左 1 人, 脱臼は右 34 人，両 13 人，左 26 人でてれも特 に発生頻度に左右差は認められなかった。

斜頭と股関節症状との関係をみると，右斜頭には左 の開排制限が多く，左斜頭では右側の脱臼が多い傾向 がみられている.

斜頭のある側とは反対側に股関節障害が現われるこ とは他の疾患例えば脳性麻疸についても言われてい る. 非対称性緊張性頸反射は正常児, 脳性麻疸児のい ずれにおいてあ右向きの方が左向きよりあ強く，ての 反射の影響下にある痙性両麻疸について Bobath は あおむけに寝た場合, 両下肢は半屈曲位になって弱々 しく動かし，一側下肢（通常は右側）はもう一側より 屯外転・屈曲している．乙の非対称的“足蹴り”は反 対側（通常は左側）の下肢の内旋を誘発し，その側の 股関節覀脱臼の発生の初期徴候となり, 少数の例では 後頭側下肢の屈曲・内旋 - 内転と側彎との変形をきた したと述べている.
股関節のX線写真でしばしば骨盤が傾いていること がある. この点について，骨盤傾斜により本来正常で あるべき臼蓋があたかむ臼蓋形成不全の如き像を呈す るため，X線撮影時，骨盤を可及的正中に保持しなけ ればならないといわれている. しかし逆にいえば，乙 の骨盤の傾斜・回旋は骨盤帯周囲筋の筋緊張の asymmetry によるあのであり，先天股脱をひき起す一 因之考えられるのではなかろうか. 事実, 生下時には 脱臼がなくても数力月間斜位姿勢をとり続けることに より，骨盤の挙上側（股関節の内転側）に股関節脱臼 が生ずるといわれている。

\section{3. ハンドリングについて}

筋性斜頸, 片麻瘒, 先天股脱などの明らかな疾患に 対しては，その治療を行なうのは当然であるが，その 前段階にある斜位乳児を含む運動機能発達障害児に対 しては, 経過観察と共にハンドリングの指導も有用と 思われる. 図 1 は実際に母親に渡して指導している八 ンドリング法でこれは乳児初期に使用している。

具体例をいくつか示すと，まず寝かせ方についてて あるが，新生児では半側臥位とし，乙れを左右交互に 行なわせる．折りたたんだバスタオルを背中に当て， 頭部は自由に動かせるように何も当てないでおく，徐 徐に半側臥位から側臥位へ，更に頭のコントロールが できる頃には腹臥位に寝かせるよう指導している．新 生児では頭の変形を作らないことが当初の目的である が，乙の方法は筋性斜頸にも応用でき，左筋性斜頸で は先ず左下の半側臥位で寝かせ，母親が相手になれる 時間には腹臥位にするようすすめている．また視・聴 刺激や授乳時やだく際には左上方に向くようにさせる のは当然のことである. 筋性斜頸に対して矯正位保持 用の枕や装具ああるが，頭を固定するよりあ自由に動 かさせながら反対方向へ向くようしむけるのが better と考える. また頭部の立ち直り反応を利用したり Vojta 法も応用される.

最初から腹卧位に寝かせる方法もあるが，新生児を いきなり腹臥位にすると，股関節が伸展・外旋を強制 されることにより股関節脱臼を起すおそれがあると 之, 周産期に何らかの異常のある, いわゆる at risk baby では，腹臥位での緊張性迷路反射，即ち屈筋座 性を強めてしまうおそれがあるために，当初は半側臥 位または側臥位で寝かせるよう指導し，児の状態をみ ながら，昼間短時間だけ腹卧位にし，次第に昼間腹臥 位で遊ばせる時間を長くとらせるようにしている，児 
ハンドリングの 例

正常な運勤機能の発達のためには、日常生活におけるhandling (ハンドリング、取扱い方)に対する配虑が必要。

1）腹 卧位（はらばい）

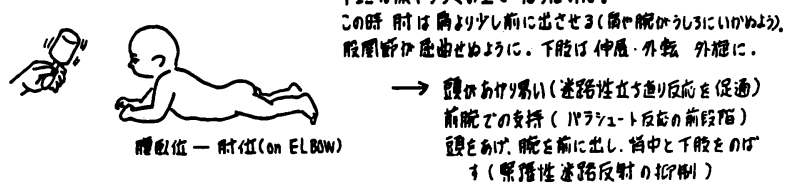

pivot (横に通い回る運動)
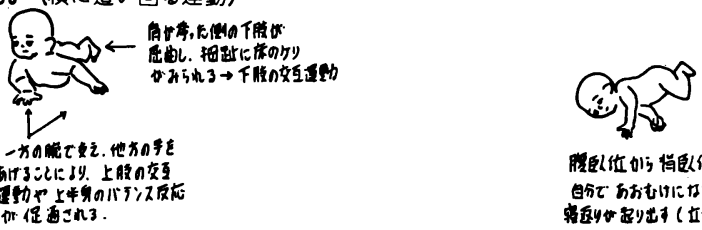

股卧值们能卧位へ。

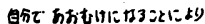

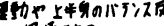

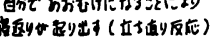

2) 畹かせ方 (半側卧位 〜 腹卧位)

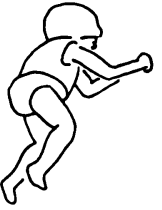

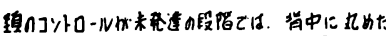

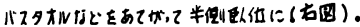

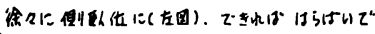
客极世级。

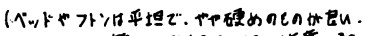

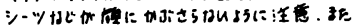

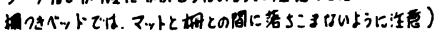

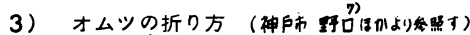

ฉ) 新生児のために
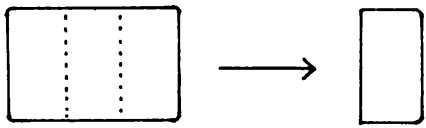

は枚をろッ折にする

b) 生後3 月月以後の児のために
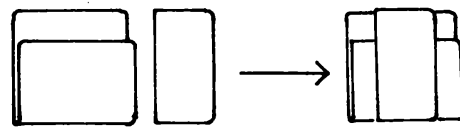

2枚をかさねる
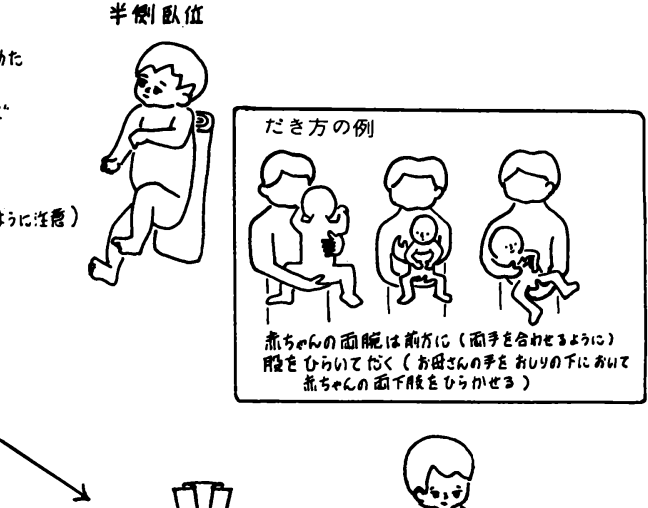

鎹 2 \%折 + 横3ッ折

赤ちゃんの自然なあしの形（屈曲位）を保つためには、おむつカパーにも注意を。

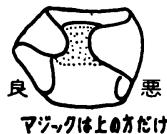

アジークは上ด方だけ tatdali cas
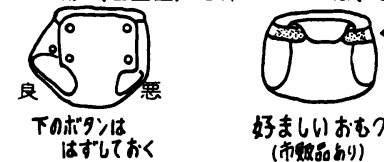

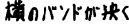

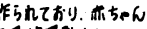

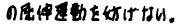

好ましいおむつかパ(市)

4)

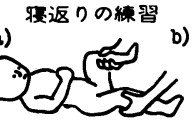

膝を柽く保持して 一方の下肢を屈曲

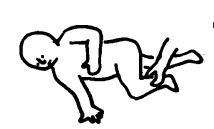

曲げた膝を 反対側の床へ o)

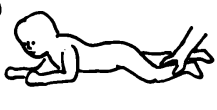

(児の上半身は

自分て起きあがらせる)
「はいはい」の練習

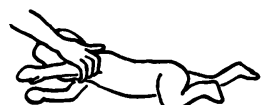

児の両周を保持し、一側の䎴を

前・上方へひく问側の下肢が

屈曲してくる)。これを左右交互

に繰り返す。

図 1 


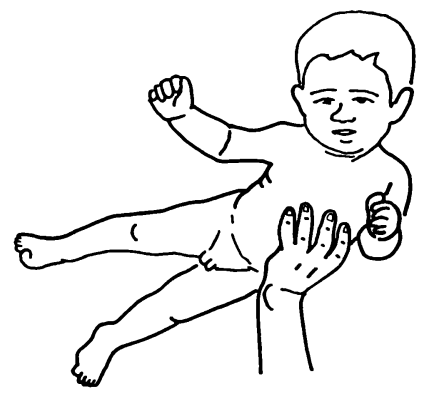

图 2 Oblique suspension

児の骨盤部を両手で保持して，かかえあげ，ゆっ くり側方または前側方へ傾ける，児を検者の両膝 の上に坐らせておいて，㯟の高さを交互に変えて も同様の反応が得られる.

の状態にもよるが生後 4 力月以降は昼夜とも腹臥位に して構わないものと考える．母親に腹臥位にするよう 告げるとよく「何分くらいはらばいにさせればいいの か」という質問を受けるが，何時間毎に何分というの ではなく, 授乳前やオムッ交換時, 目覚めて機嫌のよ い時に腹臥位にさせ，嫌がって強く泣いたり，異常姿 勢緊張が出てそりかえったりする時には中止するよう 説明している. 1 回の時間は短かくとも，回数をでき るだけ多くするよう勧めている．また児だけ腹臥位に するのでなく，母親も一緒に腹臥位になって前や側方 から呼びかけてあやしたり, 追視をさせたり, 玩具に 対して手をのばして取りにてさせたりして, 絶えず児 の相手になってやる事が重要である.

図 1 にある hand foot reflex を利用した creeping exercise のほかに, Galant 反射, Landau 反 射, 足背外側部の皮膚刺激による足関節背屈運動, 図 2 のような立ち直り反応や平衡反応を利用した oblique suspension, back tilting による背屈, その 他日常生活では乳児への呼びかけの方向, pivotや creep や crawl の方向（例えば側彎がある児では側 彎が矯正される方向に這わせる）などにも注意を払わ せている.

最近少なくなったが，先天性内反足ではギプスによ る矯正が行なわれるが，ギプスによる形態的な矯正と 共に, ギプス除去時, 足背部外側部の皮傎刺激（指先 でてすってあよいし，ブラシであよい）により足関節 背届筋や外反筋を強化することにより機能的改善をは かるのも一法であろう.

斜視では 3 才前後に眼科的治療が行なわれるが，そ
れまで放置するのではなく側方追視を行なわせること により視力や眼筋機能を少しであ改善しておくことも 有用之思われる.

\section{4. 結果と考按}

斜位乳児の大部分は正常な発達をとげており，神経 学的検査であ Galant 反射の左右などを除くと特に異 常所見は見い出せなかった.

斜頭と利き手との関係についても, 利き手が生活習 慣や社会的慣習によって修飾されている可能性があっ て，関連を見い出すことはできなかった.

斜位乳児の殆んぞが正常化していく中で，ハンドリ ングの指導を長期にわたって行なっている 2 症例につ いて述べる. 一例 はレックリングハウゼン病の 女児 で，祖父および父親にも同一疾患を認める４４力月の 時より pivot, Landau 反応の促通, oblique suspension などの exercise を強力に行なわせ 2 才 6 カ月の現在, 立位で軽い左への脊柱傾斜がみられるが これも固定性ではなく，また側彎・亀背も認めない。

二例目は軽い右片麻瘨で, 8 力月の時, 脊柱 $\mathrm{X}$ 線にて 左凸C状の側彎が見られたが，次第に改善し 2 才 3 力 月の時の $\mathrm{X}$ 線では腰椎下部を除いてほぼまっすぐにな っている.

筋性斜視の中には自然治瘉する例ああり, 軽い筋性 斜頸, 運動発達遅延, at risk baby などで治療を要 する程病的ではない場合，ただ単に外来にて経過観察 するのではなく，より良い方向に発達するようハンド リング法を母親に指導しながら，より能動的な経過観 察を行なうのが望ましいもの之考える.

最後に四肢機能の左右差について正常者(主に成人) をテストしたのでその結果を報告する．机の上の物を とる，片手をあげる，うしろを振り向かせる，横坐 り, 片脚起立, ケンケン, ボールけり, 歩き始めの 足, 台あがり，台抢り，走り幅とびの項目についてど ちら側で行なうかを観察した. 右利き正常者 13 人に ついて観察した結果，左右差が大きかったのは，「机 の上の物をとる」「片手をあげる」「ボールけり」の 3 項目で，全員が右手または右足で行なっていた(100 \%). そのほか「歩き始めの足」「台あがり」「台おり」 の 3 項目を右足で行なう者が多かった (69〜85\%). この結果, 四肢の機能を静的（支持）と動的とに分け た場合，右利きの者では右上・下肢は動的，左下肢は 支持的であることが示唆された. 


\section{ま と め}

1）斜位乳児の大部分は正常発達をとげている.

2) at risk baby, レックリングハウゼン病など の脊柱変形をきたすおそれのある疾患では斜位障害の 予防のために, oblique suspensionなどの自律反応 を利用したハンドリング法の指導も有用と思われる.

3）斜頭と利き手との間には関連を見い出しえなか ったが, 右利きの正常者では右下肢む動的な面に関与

している傾向があった.

\section{文献}

1) Bobath B. 著, 梶浦ほか訳: 脳性麻㿎の異常 姿勢反射. 医歯薬出版, 東京, 1973.

2) Bobath B. \& K. 著, 梶浦ほ加訳: 脳性麻痷 の類型別運動発達. 医歯薬出版, 東京, 1978.

3） Bernbeck, Sinios 著, 鈴木良平訳：小児運動 器疾患の早期診断法. 医歯薬出版, 東京, 1977.

4) Gladel W.: Atypische Säuglingsskoliose. Z. Orthop., 110, 140 145, 1972.

5) Müller H.: U̇bergänge von Säuglingsfehlhaltungen $z u$ "Idiopathischen" Skoliosen. Z. Orthop., 110, 223 233, 1972.

6) Fettweis E.: Erwiderung auf die Bemerkungen von H. Mau über die Arbeit des Verfassers "Zur Prophylaxe des kindlichen Hüftluxationsleidens.” Z. Orthop., 110, 272 275, 1972.
7)野口耕司ほか：新生児先天股脱の診断と治療の 検討. 整形外科, 29巻, 3 号, 219 225, 1978.

8) 小武守研二: Seitendisharmoniesyndrom. 整形外科, 28 巻, 1 号, 24,1977 .

9）サイボルト M.: 脳性麻㾘の早期治療. 総合リ 八. 2 巻 3 号, 219 233, 1974.

解 答長崎県立整肢療育園 川口 幸義

(1) 斜位姿勢の正常と異常との鑑別点は：

厳密に境界線を引くことはできませんが, 特に変形 がない「正常」之, 整形外科的治療を要する「病的」 なあのとに分け，その中間にあって治療を要する程で はないが正常ともいえないすのを「異常」と区別して いる．股関節でいえば，開排制限や軽い臼蓋形成不全 の認められる児は殆んど正常発達をとげているが, 一 応異常として home handling を指導しており，臼 蓋形成不全に亜脱臼を伴ったものや脱臼のある児では 病的として整形外科的治療を開始する（むちろん病的 なあのにあ home handling の指導は必要です).

(2) 脊柱変形や頭部変形の傾向について:

軽い変形む加える之, 頭部変形のない乳児は少なく 4 人に 1 人位で, 右斜頭が多くて半数近くみられる.

乳児の脊柱は, 非対称性緊張性頸反射の影響を受け ている場合之， $4 ， 5$ 力月以後に強くなる抗重力的な 伸展緊張の影響を受けている場合はカーブが異なるの で，一概には言えないように思う. 